\title{
The practical application of information technology in marketing
}

\author{
Yanyang $\mathrm{Ma}^{1}$ \\ ${ }^{1}$ Xichang University, 615013
}

\begin{abstract}
Marketing is a discipline closely related to social and economic development. In the teaching practice of marketing, we should scientifically and comprehensively reform the teaching methods of education and actively apply information technology to effectively and effectively improve the overall quality of marketing. And level, to better improve the overall literacy and cognitive abilities of students.
\end{abstract}

\section{Introduction}

At this stage, the continuous progress of the information age makes information technology bring new challenges to classroom teaching reform, and put forward brand new requirements for teachers' teaching. When carrying out teaching work, teaching concepts, teaching models and teaching methods must adapt to the development of the times. Marketing itself is a core characteristic course that closely fits the practice. In the education and teaching practice of marketing, it should be fully and comprehensively combined with information technology to form a complete education program, and better Improve the quality and effectiveness of education and teaching, and comprehensively improve students' information literacy and overall cognitive ability. Information-based teaching methods are mainly based on modern information technology, applying multimedia technology, network technology, virtual reality technology, artificial intelligence technology, etc. to the teaching process. ${ }^{[1]}$

\section{Relevant overview of information teaching}

With the continuous and rapid development of information technology, information-based teaching has become the main method of teaching at this stage. Informatization teaching is developed and evolved in the process of continuous development of information technology, and it is an efficient teaching organization mode. In the teaching practice of marketing, information technology should be used scientifically and comprehensively to innovate and reform the education and teaching mode. In information teaching, the current teaching thought is regarded as the guiding ideology, information technology is the support, and modern teaching methods are adopted. Through informationbased teaching, teachers act as the disseminators of knowledge and convey knowledge to students. Students are changed from external stimulators and knowledge transmitters to information processors and active knowledge builders. The media has also become a cognitive tool that transforms teachers' explanations and presentations into students' self-directed learning and exploration and solving practical problems. Students can use this to search for information and search for information. The focus of marketing teaching reform is to change the previous form of indoctrination in the classroom. Informatization teaching is a very effective mode in the exploration of marketing teaching reform.

\section{The necessity of the reform of marketing informatization teaching}

Marketing is a characteristic subject closely integrated with practice. In the education and teaching practice of marketing, it should actively and effectively conform to the development trend of the times, effectively promote the in-depth information teaching, and comprehensively carry out the reform of information teaching. It can be said that in the educational practice of marketing, it is of very important practical significance to thoroughly and comprehensively do a good job in the reform of informatization teaching. On the one hand, actively and effectively promote the reform of marketing informatization teaching, which can enrich the course content to a large extent, and at the same time can improve students' practical literacy and cognitive vision in an allround way, and better consolidate their learning effectiveness. It can be said that the requirements of the future society for marketing students are very high, not only require students to have solid practical literacy, but also require them to have a solid theoretical understanding, strong practical ability, market insight ability and research Ability and so on. Through the in-depth advancement of information-based teaching, it can not only provide students with broad learning resources, but also optimize students' cognitive literacy to a large extent. It can also enhance students' autonomous learning ability in an allround way, and better cultivate social needs. High-quality talent. In the practice of informatization teaching, the 
subjective status of students has been fully embodied. Under the guidance of teachers, they can consciously and actively use the information platform to carry out autonomous learning. This efficient teaching organization model can further consolidate students' learning effectiveness, improve their learning quality in an allround way, and further promote their growth and development. On the other hand, in the teaching practice of marketing, the active use of information technology can also effectively change the teaching organization mode and better stimulate students' interest in learning. It is undeniable that in the teaching process of traditional marketing, teachers and students are confronted with each other. Teachers subjectively teach courses, students passively accept and learn knowledge, which often affects to a large extent. And it restricts students' learning effectiveness, and it is difficult to truly optimize their cognitive literacy. Through informatization teaching reform, it can promote the effective conversion of the roles between teachers and students, can better play the guiding role of teachers, and can also enhance students' subjective initiative in an all-round way. ${ }^{[2]}$

\section{Requirements for the integration of marketing and information technology}

In the education and teaching practice of marketing, the traditional teaching organization model has big drawbacks and shortcomings, which affects the quality of education and teaching to a large extent, but also is not conducive to improving the overall quality of students. In the process of continuous development of information technology, a thorough and comprehensive grasp of the internal relevance between marketing and information technology, and actively and effectively promote the reform of information teaching, not only can improve the overall educational effectiveness of marketing, but also To a large extent, it consolidates students' practical literacy and optimizes students' cognitive level in an all-round way. In the course of practice, in order to effectively integrate marketing and information technology, it is necessary to accurately and comprehensively grasp the internal requirements and consolidate the quality of education and teaching to the greatest extent.

\subsection{Update of teachers' teaching philosophy}

In the process of informatization teaching of marketing, teachers are very important participants. Their own thinking and concepts, their own teaching concepts, etc., are often related to the education quality of marketing and directly related to the level of information teaching. In order to better promote the in-depth informationization of teaching, we must focus on the comprehensive update and transformation of teachers' teaching concepts, and carry out efficient adjustments and changes from the ideological and cognitive level, so as to consolidate teachers' teaching quality to the greatest extent and further improve them. Professional ability. In order to ensure the reform and promotion of marketing information teaching, the school should focus on creating an efficient talent training system, effectively cultivating a group of high-quality teachers with strong professionalism, and effectively improving the teaching skills of teachers and the development and design of teaching media. ability. At the same time, the school should also set up a sound teaching and research team to carry out a full range of innovations and discussions on the integration of marketing and information technology. In addition, the school must use systematic vocational skills training and competition systems to effectively stimulate the enthusiasm of teachers to participate, and to consolidate their practical literacy and teaching organization and management capabilities to the greatest extent.

\subsection{Make necessary investment in teaching software and hardware}

In the process of continuous development of information technology, actively and effectively integrate marketing and information technology to better provide the necessary conditions for information teaching, and the investment and management of software and hardware should be effectively promoted. Hardware investment is the fundamental and prerequisite for the development of informatization teaching. The effective replacement of equipment and the purchase of hardware provide a solid foundation for the school to create modern educational technology features. According to current technology, the fundamental characteristics of education informatization are digitization, network intelligence and multimedia. ${ }^{[3]}$ Schools with a certain level of strength need to build multimedia classrooms such as electronic reading rooms and digital libraries. According to calculations in the China Education Statistics Yearbook 2019, nationwide, the Internet access rates of elementary schools, junior high schools, and ordinary high schools have reached $68.06 \%$, $92.43 \%$, and $96.26 \%$, basically reaching the level of popularization. It can be said that in the process of advancing informatization teaching, in-depth and comprehensive strengthening of the investment and construction of software and hardware facilities is a very necessary investment and a relatively large investment in education. In order to better improve the overall quality and effectiveness of informatization teaching of marketing, and to consolidate the overall strength of informatization teaching in an all-round way, it is necessary to make efficient and scientific software and hardware investment.

\section{Practical application of information technology in marketing}

Marketing itself is a characteristic subject with quite practical attributes. In the education and teaching practice of marketing, information technology methods should be thoroughly and comprehensively applied to further improve the overall teaching quality of marketing and better consolidate students. Practical literacy and cognitive ability. It can be said that informatization teaching has become an important organization method of marketing teaching, and it has become an important teaching form of marketing. In order to give full play to 
the overall application of information technology, it is necessary to fully grasp the characteristics of marketing and apply information technology in a scientific and comprehensive manner.

\subsection{Efficient use of marketing information platform}

In the education reform practice of marketing, the efficient application of information technology plays a very important practical role. In order to better improve the effectiveness of education and teaching, it is necessary to accurately and comprehensively grasp the information technology means, and build a scientific and comprehensive marketing information platform. It can be said that the construction of an information platform for marketing can lay a solid foundation for the advancement of information teaching, and it can also help deepen the reform of marketing education, as shown in Figure 1. At the current stage, the construction of the marketing informatization curriculum system has achieved outstanding results. In the network platform, the type, quantity, content, etc. of marketing information education resources are relatively complete and extensive, which has laid a solid foundation for education and teaching. In order to make better use of the information teaching platform, an efficient course organization should be carried out to effectively improve the effectiveness and level of marketing information teaching.

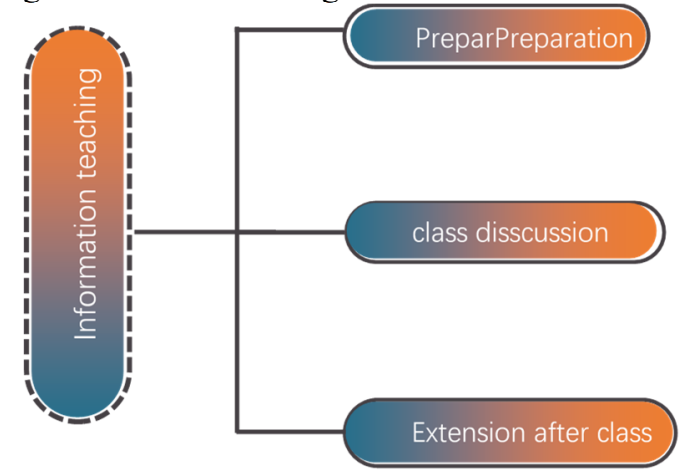

Figure 1: The architecture system of informatization teaching

\subsubsection{Realize pre-class preparation with micro- classes, etc.}

The deepening of the reform of marketing informatization teaching provides good conditions for students to learn independently, and at the same time, it also greatly enhances students' subjective initiative. In order to make better use of the overall application effectiveness of the marketing information platform, teachers should fully and comprehensively play the role of teaching guide, scientifically and comprehensively make fine and comprehensive pre-class preparations. It can be said that efficient pre-class preparation can clarify the learning direction and goals for students, and can also guide students to use the information platform to familiarize themselves with and recognize courseware resources in advance. In the process of practice, with the teaching characteristics and requirements of marketing as the core, students are required to use the information platform to learn or download related teaching content before teaching, familiarize themselves with the teaching outline in advance, and then set up relevant questions to guide students to think according to the outline requirements. According to the case in the network-assisted course, students are required to collect materials that they are interested in when collecting materials, and prepare for class discussion. Through the independent study of students, they can prepare for study in advance according to the relevant content in the information platform $\cdot{ }^{[4]}$ Relying on this approach, it can not only fully mobilize students' interest in learning, but also help students recognize the problems and obstacles in autonomous learning in advance, so as to better consolidate the effectiveness of students' learning.

\subsubsection{Conduct classroom discussions with multimedia technology}

In the education and teaching practice of marketing, the in-depth and comprehensive use of information technology means, and the active development of extensive and in-depth classroom discussions and interactions can consolidate students' learning effectiveness to a large extent, and at the same time create good results for students. Classroom discussion situation. In the specific process of classroom discussion, teachers should combine the needs of the curriculum and make effective use of multimedia technology. It can be said that, compared with traditional classroom lectures and flat board newspapers, the application of multimedia teaching situations can fully display the relevant knowledge and content of marketing to students, and guide them to conduct in-depth and effective learning and exploration. . Relying on pre-class learning, in the process of organizing students to discuss in class, teachers can use multimedia to display relevant cases or courseware resources, etc., to guide and encourage students to conduct in-depth and systematic discussions and learning about these cases or courseware resources. In classroom discussions, teachers can divide students in the class into groups and guide them to conduct in-depth and extensive interactions and exchanges in groups to better consolidate the effectiveness of classroom learning. For example, teachers can use multimedia teaching technology to effectively adopt different methods such as videos, animations, pictures, audios, etc., to effectively and effectively enhance students' cognitive interest, and better enhance students' subjective initiative. In addition, in information teaching, teachers should also combine the professional qualities and learning cognitive level of different students to effectively create differentiated teaching situations and truly realize personalized teaching.

\subsubsection{Use an information platform to organize after- school discussions}

In the education and teaching practice of marketing, the scientific and efficient application of information technology can create a scientific and good learning 
platform for students, and at the same time, it can better guide students to discuss and interact. For this reason, in the after-school stage, teachers should actively create tasks for after-school discussions based on the information platform, encourage and guide students to use the afterschool platform for in-depth communication and interaction. In the process of after-class extension and discussion, students can use a wide range of network platforms to communicate and interact with teachers and students at a wide range of levels. At the same time, in the extension and expansion stage after class, teachers should also set up an online test section based on the information platform to guide students to actively participate in online answering questions based on the learning results of marketing before and during class, and quickly test their learning ability and Level of learning. Teachers can use the online platform to grasp the learning progress and learning situation of students, so as to give students necessary teaching guidance in time. ${ }^{[5]}$

\subsection{Application of Social Network Analysis in Marketing}

The analysis of social network is a kind of social relationship structure mainly produced by the interconnection between individuals. It is a scientific, reasonable and standardized social relationship structure, which can effectively analyze the social relationship structure and emphasize the relationship between social subjects. The relationship between, reveals the subject matter in the society, and then conducts a quantitative analysis on it. In recent years, my country's computer technology and network technology have been rapidly developed, and the level of social network analysis has gradually improved, and it has been widely used in marketing. With the continuous and rapid development of information technology, in the education and teaching practice of marketing, marketing and information technology should be efficiently integrated to form a complete and systematic teaching organization model to better improve students' Learning effectiveness. It can be said that the application of information technology provides perfect ideas for the development of marketing and also creates a broad platform. In the practice of informatization teaching, social network analysis is a very important foothold. If there is no comprehensive and systematic social network analysis, or no scientific curriculum content as a support, it will inevitably affect and restrict the deepening of the teaching of marketing to a large extent. To this end, teachers should combine practical needs to scientifically and comprehensively create teaching content. In practical applications, opinion leaders should be discovered scientifically and comprehensively. At the same time, big data technology should be used to re-evaluate customer value, and big data technology should be fully relied on to consolidate the teaching effectiveness of the course.

\subsection{Use mature websites to use the "content + service" model}

Marketing is a highly practical subject. In the course of course teaching, whether it is to adopt traditional teaching mode or construct an information-based teaching platform, we should pay attention to in-depth and comprehensive implementation of good practical teaching. In order to effectively enhance students' practical ability and to further consolidate students' curriculum literacy, teachers should base themselves on the curriculum characteristics of marketing and make effective use of various information-based teaching techniques. On the one hand, mature websites can be fully utilized in information teaching. Use professional marketing websites, such as: National Bureau of Statistics, China Marketing Network, China Marketing Network, etc. Among them, the National Bureau of Statistics can provide a large amount of economic data for marketing environment analysis and market research, so that students can grasp the latest and most comprehensive marketing macro environment, and refer to these big data in the process of product selection to help make correct decisions.

For example, teachers create corresponding practical tasks for students of different literacy, guide and encourage them to use the information platform to search and develop related resources, complete their respective exploration tasks effectively, and better improve students' practical literacy. On the other hand, in the educational reform of marketing, teachers should also use the "content + service" model to guide students to actively use a broad platform to optimize their learning literacy.

\section{Conclusion}

In the education and teaching practice of marketing, the application of information technology has a very important practical effect. In order to better improve the teaching effectiveness of marketing, and to better consolidate students' practical literacy, we should scientifically and comprehensively promote the in-depth information teaching work, and better improve the overall teaching quality of marketing.

\section{References:}

1. Mao Linglin, He Xin. Research on the Development and Application of SPOC Curriculum of "Marketing" in Local Colleges and Universities under the Background of Information Technology[J]. Teaching and Education (Higher Education Forum), 2019(4): 63-65.

2. Zhu Hong. Research on the Strategy of Improving the Teaching Quality of "Marketing" Courses in Secondary Vocational Schools under the Visual Threshold of Digital Aggregation[J]. Seeking Knowledge Guide, 2018(15):103-105.

3. Zhang Hongjun. Reform of "Marketing" teaching system in applied colleges and universities[J]. Teaching and Education (Higher Education Forum), 2019(7): 80-81. 
4. Wang Jingjing. Discussion on the ideas and methods of the teaching reform of the "Marketing" course[J]. Science Education Journal-Electronic Edition (midday), 2019(4):127.

5. Li Yunqin, Zhang Li. Research on marketing teaching reform under the background of "Internet + "[J]. Rural Economy and Technology, 2018, 29(16): 300. 